\title{
Evaluation of the Physical and Mental Development of Children with Diffusive Goiter in the State of Euthyroidism
}

\author{
Jafarova Parvina Bakhodurovna* and Juraeva Aziza Shahzadeevna \\ Department of General and Pediatric Endocrinology, Tashkent Pediatric Medical Institute, Uzbekistan
}

Submission: August 19, 2019; Published: September 17, 2019

*Corresponding author: Jafarova Parvina Bakhodurovna, Resident in the Department of General and Pediatric endocrinology, Tashkent Pediatric Medical Institute, Bagishamal strt, 223 Yunusabad region, Tashkent city, Uzbekistan

\begin{abstract}
To date, in Central Asia, a small amount of research evaluating the influence of diffuse goiter of various degrees in the state of euthyroidism
\end{abstract} on mental and physical condition of children.

Aim: Evaluate the mental and physical data of children with diffuse goiter in the state of euthyroidism.

Materials and methods: We examined 23 children from 7 to 16 years old (15 girls) with DG of varying degrees in a state of euthyroidism.

Results: In 14 (60,9\%) patients, SDS of height and body weight were noted at the level of medium values; in 9 (39,1\%) patients SDS of height and weight were below average quantities. $19(82,6 \%)$ patients had an average level of IQ; in $4(17,4 \%)$ patients the IQ level was lower than the normal.

Conclusion: Despite the euthyroid state, children and adolescents with diffuse goiter note some decline in physical and mental development, and the greater the degree of increasing thyroid gland, this more expressed.

Keywords: Diffuse goiter; Euthyroidism; Physical and Mental development; Hypothyroidism

\section{Relevance}

To date, in Central Asia, a small amount of research evaluating the influence of diffuse goiter of various degrees in the state of euthyroidism on mental and physical condition of children [1,2]. This causes the need to study this problem for timely prevention of hypothyroidism [3-5]. According to the latest studies conducted in the Republic of Uzbekistan in 2016, among 39605 examined high-school students, diffuse goiter (DG) first degree was found in $20.5 \%$ of children, a second-degree in $7.9 \%$; the prevalence of endemic goiter was $28.6 \%$.

\section{Materials and methods}

We examined 23 children from 7 to 16 years old (15 girls) with DG of varying degrees in a state of euthyroidism. The degree of enlargement of the thyroid gland was determined by the WHO classification (2001) by manual exam. Height and body weight were compared with WHO centile tables. To determine the degree of growth deviation from average values, the standard deviation index (SDS) was calculated individually for each patient. Plasma levels of thyroid stimulating hormone (TSH) and free thyroxine (T4) were also determined. To assess the IQ level, the Raven progressive matrix method was used.

\section{Results}

In $14(60,9 \%)$ patients, SDS of height and body weight were noted at the level of medium values; in $9(39,1 \%)$ patients SDS of height and weight were below average quantities. 19 (82,6\%) patients had an average level of IQ; in $4(17,4 \%)$ patients the IQ level was lower than the normal. At the same time, it was found that the greater the degree of increasing the thyroid gland, the lower the physical and mental indicators.

\section{Conclusion}

Despite the euthyroid state, children and adolescents with diffuse goiter note some decline in physical and mental development, and the greater the degree of increasing thyroid gland, this more expressed. 


\section{References}

1. Devries L, Bulvik S, Phillip M (2009) Chronic autoimmune thyroiditis in children and adolescents: at presentation and during long-term followup. Arch Dis Child 94(1): 33-37.

2. Kundra P, Burman KD (2012) The effect of medications on thyroid function tests. Med Clin North Am 96(2): 283-295.

3. Patrick Hanley, Katherine Lord, Andrew J Baue (2016) Thyroid Disorders in Children and Adolescents. JAMA Pediatr 170(10): 10081019.

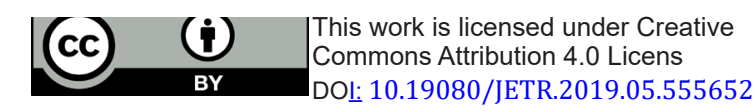

4. Nosrat Ghaemi, Rahim Vakili, Sepideh Bagheri (2013) Precocious Puberty: An Unusual Presentation of Hypothyroidism. International Journal of Pediatrics 1(2): 51-54

5. World Health Organization (2014) Goiter as a Determinant of the Prevalence and Severity of Iodine Deficiency Disorders in Populations, Geneva, Switzerland.

Your next submission with Juniper Publishers
will reach you the below assets
- Quality Editorial service
- Swift Peer Review
- Reprints availability
- E-prints Service
- Manuscript Podcast for convenient understanding
- Global attainment for your research
- Manuscript accessibility in different formats
( Pdf, E-pub, Full Text, Audio)
- Unceasing customer service
Track the below URL for one-step submission
https://juniperpublishers.com/online-submission.php

